\title{
Synthesis of functionalized macrocyclic derivatives of trioxabicyclo[3.3.0]nonadiene
}

\author{
Sabine Leber ${ }^{1,2}$, Gert Kollenz ${ }^{* 1}$ and Curt Wentrup ${ }^{* 2}$
}

\section{Full Research Paper}

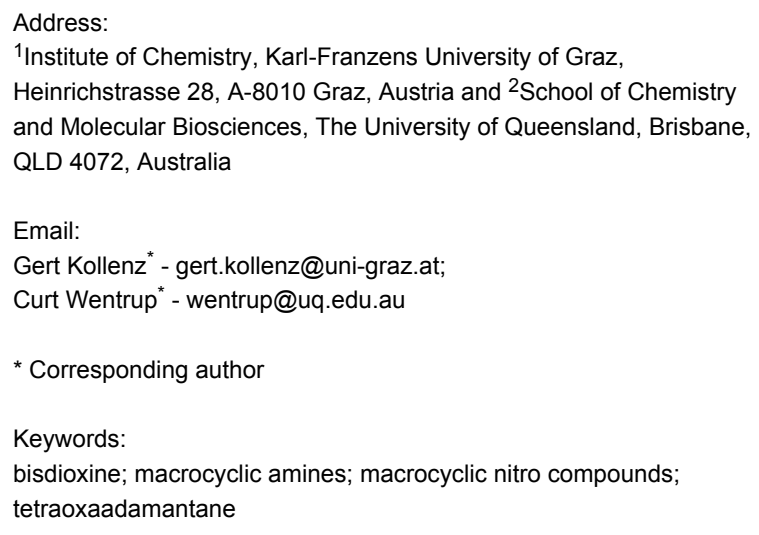

\begin{abstract}
\section{Introduction}

The concave, axially chiral [1], bridged bisdioxine diacid dichloride $\mathbf{3}$ is obtained by acid hydrolysis and subsequent chlorination of the surprisingly stable $\alpha$-oxoketene 2 , itself obtained by dimerization of dipivaloylketene (1) (Scheme 1) [2,3]. The concave structure of $\mathbf{3}$ and its derivatives together with the sterically hindering tert-butyl groups make it an interesting spacer group, and it thus has been applied successfully in syntheses of several macrocyclic polyether and polymethyleneoxy rings containing one, two or three bisdioxine units, e.g., 4 and $\mathbf{5}$ (Scheme 1) [4,5]. Capping of a calix[6]arene with the bisdioxine unit has also been achieved recently [6]. Some of these materials exhibit pronounced complexation of metal ions, such as $\mathrm{Cs}^{+}, \mathrm{Hg}^{2+}, \mathrm{Cu}^{2+}, \mathrm{Ag}^{+}$, and $\mathrm{Au}^{3+}[5-7]$.
\end{abstract}

$\mathrm{C}_{72}$-Macrocyclic systems functionalized with nitroaryl and arylamino groups were synthesized from the bisdioxine diacid dichloride 1,3,5,7-tetra-tert-butyl-2,6,9-trioxabicyclo[3.3.1]nona-3,7-diene-4,8-dicarbonyl dichloride (3).

It may also be possible to stabilize reactive intermediates and unusual functional groups in the concave interiors of the bisdioxine-derived macrocycles. Okazaki and co-workers designed bowl-shaped [8] and lantern-shaped [9] molecules containing a functionalized aryl group, which allowed the preparation of, among other things, stable simple enols [8] and a variety of unusual sulfur [9], selenium $[10,11]$ and germanium [12] species. Clearly, the bisdioxine macrocycles such as $\mathbf{4}$ and $\mathbf{5}$ will not be nearly as rigid, but they may nevertheless exert some steric protection. Herein we report the realisation of the first step toward this end, the preparation of functionalized macrocyclic bisdioxine derivatives. 


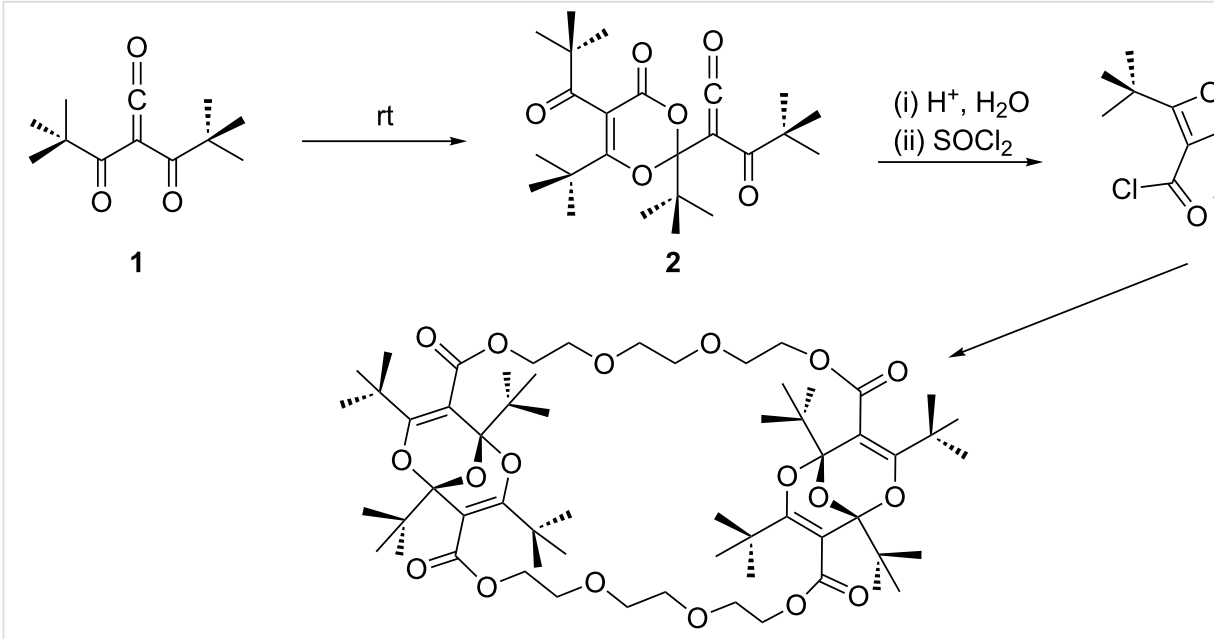

4
3

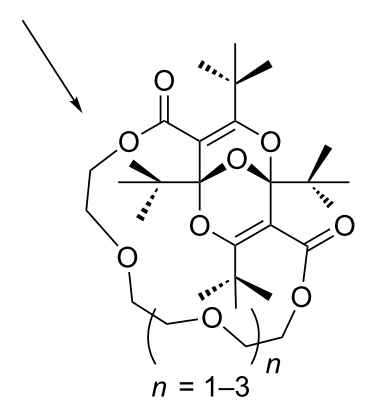

5

Scheme 1: Synthesis of macrocyclic bisdioxine derivatives ( $R, S$-form of $\mathbf{4}$ and $S$-form of $\mathbf{5}$ shown; see Supporting Information File 1 for details).

\section{Results and Discussion}

Functional group manipulation on aromatic rings often starts with the nitro group. Therefore, a synthesis of suitable nitroaromatic diols for combination with the diacid dichloride 3 was required. The desired 2-nitro-1,4-phenylene derivative 7 was prepared by treatment of hydroquinone with 3-bromopropanol followed by nitration of the resulting diol $\mathbf{6}$ (Scheme 2). The isomeric 1,2,3-trisubstituted aromatic $\mathbf{1 0}$ was obtained by etherification of nitroresorcinol (Scheme 3).

$$
\begin{aligned}
& \text { (c) }
\end{aligned}
$$

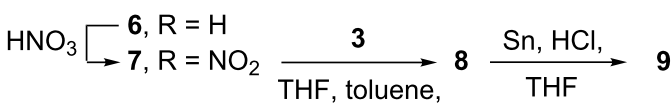

$$
\begin{aligned}
& \mathrm{Et}_{3} \mathrm{~N} \text {, reflux }
\end{aligned}
$$

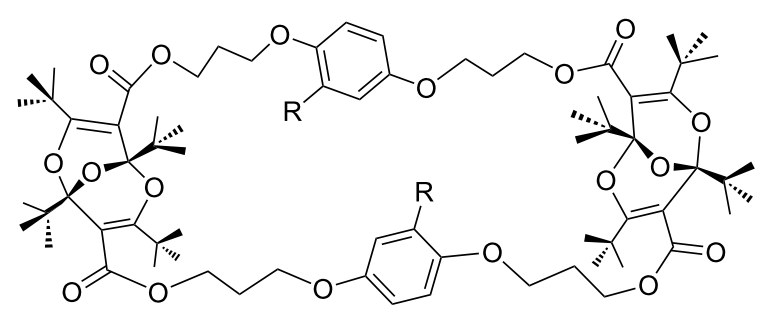

8, $\mathrm{R}=\mathrm{NO}_{2}$

9, $\mathrm{R}=\mathrm{NH}_{2}$

Scheme 2: Synthesis of the 1,2,4-trisubstituted aryl derivatives.

The two diols $\mathbf{7}$ and $\mathbf{1 0}$ reacted readily with the diacid dichloride 3 in boiling toluene in the presence of triethylamine to afford the 2:2 adducts 8 and 11, respectively (Scheme 2 and Scheme 3 ). These compounds were characterized by elemental

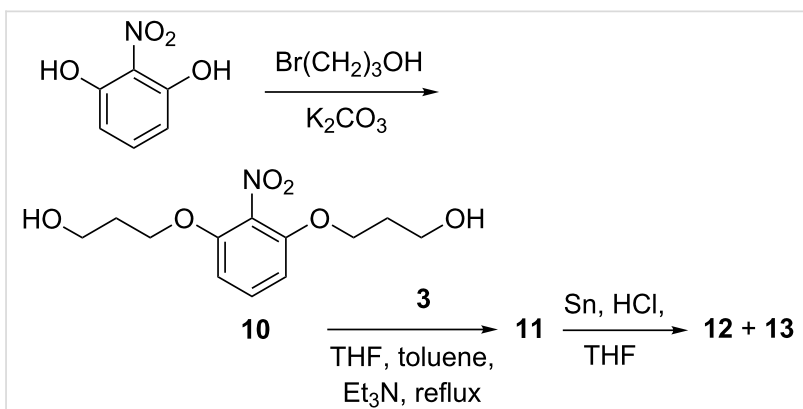

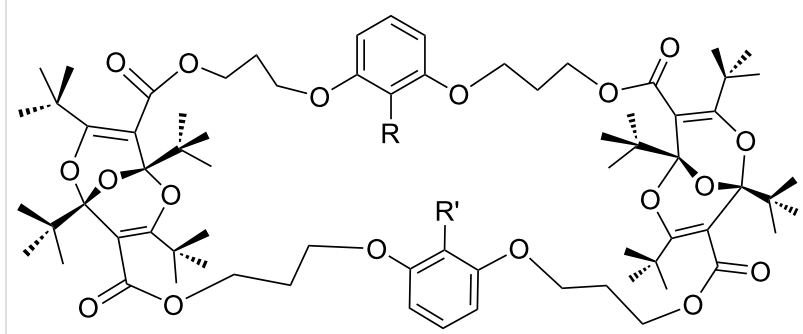

11, $\mathrm{R}=\mathrm{R}^{\prime}=\mathrm{NO}_{2}$

12, $\mathrm{R}=\mathrm{NO}_{2}, \mathrm{R}^{\prime}=\mathrm{NH}_{2}$

13, $\mathrm{R}=\mathrm{R}^{\prime}=\mathrm{NH}_{2}$

Scheme 3: Synthesis of the 1,2,3-trisubstituted aryl derivatives.

analysis and their ${ }^{1} \mathrm{H}$ - and ${ }^{13} \mathrm{C}$ NMR spectra. All proton and carbon resonances could be assigned by comparison with data for other, related, macrocycles [1-7] (see Supporting Information File 2 for spectral details). Since 3 is chiral (existing in enantiomeric $R$ and $S$ forms) [1,4], the nitro compounds 8 and 11 must also be chiral, i.e., they must exist as mixtures of diastereoisomeric forms (see the Supporting Information File 1 for drawings of the principal structures). This will also be the case for the derivatives described below. The splitting of several signals in the NMR spectra may be ascribed to the presence of mixtures of diastereoisomers and conformers. 


\section{Reduction}

Several methods were attempted for the reduction of the nitro groups in $\mathbf{8}$ and 11. Reductions with $\mathrm{NaBH}_{4}$ and sulfur [13] or with ammonium formate and $\mathrm{Pd} / \mathrm{C}$ under microwave irradiation [14] were unsuccessful. However, compound 8 was completely reduced to the diamine 9 by using the classical reduction with $\mathrm{Sn}$ and $\mathrm{HCl}$ (Scheme 2). The reaction was complete in $1 \mathrm{~h}$. Under the same conditions it took $3 \mathrm{~h}$ for the 2,6-disubstituted nitro compound $\mathbf{1 1}$ to be completely consumed. Compound $\mathbf{1 1}$ is more compact than $\mathbf{8}$ (see below), and the reduction of $\mathbf{1 1}$ was evidently more difficult. Although the product was largely the desired diamine 13, mass spectrometry indicated the presence of the singly reduced nitro derivative $\mathbf{1 2}$ as an impurity (Scheme 3).

A remarkable reaction is the ready conversion of macrocyclic as well as open-chain bisdioxine derivatives to 2,4,6,8-tetraoxaadamantanes on acid hydrolysis $[4,7,15]$. This transformation was also achieved with the dinitro compound $\mathbf{8}$, which yielded the mono-tetraoxaadamantane derivative 14 (Scheme 4), but all attempts to convert the second bisdioxine unit were fruitless, presumably due to steric hindrance. Force-field calculations [16] indicate that the internal cavity is much smaller in $\mathbf{1 1}$ than in $\mathbf{8}$, and in fact it was not possible to prepare a tetraoxaadamantane derivative of nitro compound $\mathbf{1 1}$. There is a significant cavity in $\mathbf{8}$, obviously large enough to form one tetraoxaadamantane derivative, but this reduces the available space, with the consequence that the attack by a water molecule on the second bisdioxine unit from the concave inside of the macrocycle does not take place.

\section{$8 \mathrm{HCl}, \mathrm{CH}_{3} \mathrm{COOH}$}

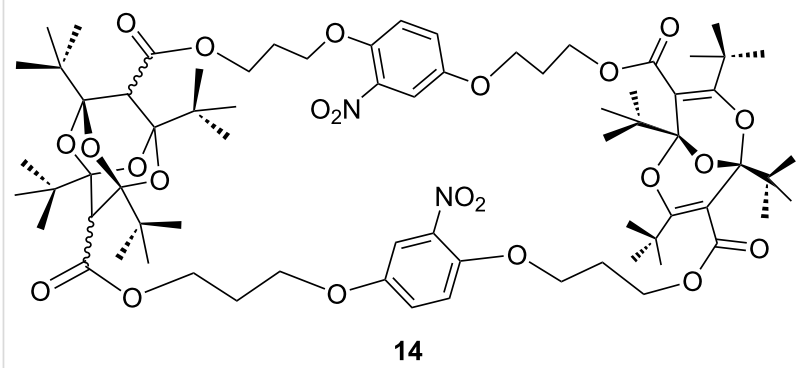

Scheme 4: Synthesis of the tetraoxaadamantane derivative 14.

\section{Conclusion}

The difficulty of reduction of the nitro compounds, in particular the 1,2,3-trisubstituted compound 11, as well as the conversion of only one of the bisdioxine units in $\mathbf{8}$ to a tetraoxaadamantane suggests that these macrocycles provide steric protection of the functional groups. The cavity in $\mathbf{8}$ is obviously large enough to permit the formation of one tetraoxaadamantane unit, but this will reduce the available space, with the consequence that the attack by a water molecule on the second bisdioxine unit from the concave inside of the macrocycle does not take place. Moreover, no tetraoxaadamantane derivative of nitro compound $\mathbf{1 1}$ was obtainable. Here, the cavity is too small for the formation of a tetraoxaadamantane. Further investigations of reactivity and functional group manipulation in the macrocycles described herein are foreseen.

\section{Experimental}

General. All solvents were dried to achieve the minimum degree of water content. Melting points are uncorrected. Drycolumn flash chromatography (DCFC) was performed according to a literature method [17] by using silicagel $6 \mathrm{H}$ from Merck, Darmstadt and eluting with $\mathrm{CH}_{2} \mathrm{Cl}_{2} / \mathrm{MeOH}$ 100:5, unless indicated otherwise. Thin-layer chromatography (TLC) was performed on silica gel. LC-MS was performed by using a mixture of $77 \% \mathrm{CH}_{3} \mathrm{CN}, 18 \% \mathrm{H}_{2} \mathrm{O}$, and $5 \% \mathrm{MeOH}$ as mobile phase, unless otherwise indicated, and an atmospheric-pressure chemical ionization source. All NMR spectra were recorded for $\mathrm{CDCl}_{3}$ solutions. Assignments of NMR signals for bisdioxine and tetraoxaadamantane units were made in agreement with previously reported data $[1-7,15]$.

1,3,5,7-Tetra-tert-butyl-2,6,9-trioxabicyclo[3.3.1] nona-3,7diene-4,8-dicarbonyl dichloride (3): Flash vacuum thermolysis of 5-tert-butyl-4-pivaloylfuran-2,3-dione generates dipivaloylketene (1), which slowly dimerizes to the dimeric oxoketene 2 at room temperature [2,3]. Hydrolysis and subsequent chlorination with thionyl chloride afforded the bisdioxine diacid dichloride 3 [3].

4,4'-(2-Nitro-1,4-phenylene)bis(4-oxabutanol) (7): Diol 6 was prepared according to the literature [18]. To a solution of 6 (750 mg, $3.32 \mathrm{mmol}$ ) in $65 \mathrm{~mL}$ of glacial acetic acid was added $22 \mathrm{~mL}$ of $37 \% \mathrm{HNO}_{3}$ under stirring. The solution turned intensely yellow immediately. After being stirred for $30 \mathrm{~min}$ the mixture was diluted with $100 \mathrm{~mL}$ of water, neutralized with aq $\mathrm{KOH}$, and extracted several times with $\mathrm{CH}_{2} \mathrm{Cl}_{2}$. The combined organic layers were dried over $\mathrm{Na}_{2} \mathrm{SO}_{4}$, filtered, and concentrated in vacuo. The resulting oily product $(1.44 \mathrm{~g})$ was purified by DCFC to yield $350 \mathrm{mg}$ (39\%) of intensely yellow crystals, mp 48-49 ${ }^{\circ} \mathrm{C} ;{ }^{1} \mathrm{H}$ NMR $\delta 2.05-2.11\left(\mathrm{~m}, 4 \mathrm{H}, \mathrm{CH}_{2}\right), 2.66$ (s, br, $2 \mathrm{H}, \mathrm{OH}), 3.86-3.93\left(\mathrm{~m}, 4 \mathrm{H}, \mathrm{CH}_{2} \mathrm{OH}\right), 4.12-4.15(\mathrm{~m}, 2 \mathrm{H}$, $\left.\mathrm{OCH}_{2}\right), 4.23-4.26\left(\mathrm{~m}, 2 \mathrm{H}, \mathrm{OCH}_{2}\right), 7.05-7.15(\mathrm{~m}, 2 \mathrm{H}$, arom. $\mathrm{H} 5, \mathrm{H} 6), 7.46-7.47$ (m, 1H, arom. $\mathrm{H} 3) ;{ }^{13} \mathrm{C} \mathrm{NMR} \delta 31.7\left(\mathrm{CH}_{2}\right)$, $31.9\left(\mathrm{CH}_{2}\right), 59.9\left(\mathrm{CH}_{2} \mathrm{OH}\right), 60.4\left(\mathrm{CH}_{2} \mathrm{OH}\right), 66.4\left(\mathrm{OCH}_{2}\right), 68.4$ $\left(\mathrm{OCH}_{2}\right), 110.9$ (arom. C3), 116.0 (arom. C6), 121.7 (arom. C5), 139.4 (arom. C2), 146.8 (arom. C1), 152.3 (arom. C4); the NMR spectra were assigned on the basis of comparison with 
standard data compilations; LC-MS $\left(\mathrm{CH}_{2} \mathrm{Cl}_{2}\right) \mathrm{m} / \mathrm{z}$ : 271; Anal. calcd for $\mathrm{C}_{12} \mathrm{H}_{17} \mathrm{NO}_{6}: \mathrm{C}, 53.13 ; \mathrm{H}, 6.32 ; \mathrm{N}, 5.16$; found: $\mathrm{C}$, $53.30 ; \mathrm{H}, 6.43 ; \mathrm{N}, 5.10$.

Bis(2-nitro-1,4-phenylene)macrocycle 8: A sample of diacid dichloride 3 (500 mg, $1.05 \mathrm{mmol}$ ) was dissolved in $25 \mathrm{~mL}$ of toluene. The diol 7 (285 $\mathrm{mg}, 1.05 \mathrm{mmol})$ was separately dissolved in $8 \mathrm{~mL}$ of toluene, and $1 \mathrm{~mL}^{\text {of }} \mathrm{Et}_{3} \mathrm{~N}$ in $17 \mathrm{~mL}$ of THF was added. The two solutions were placed in separate dropping funnels attached to a flask containing $80 \mathrm{~mL}$ of toluene, fitted with a reflux condenser and protected from moisture. The apparatus was flushed with $\mathrm{N}_{2}$. The two solutions were simultaneously added dropwise to the toluene under reflux over a $3 \mathrm{~h}$ period, and the resulting mixture was heated under reflux for $20 \mathrm{~h}$. After cooling to $60^{\circ} \mathrm{C}$ and filtering on a folded filter, the resulting solution was evaporated, and the material so obtained was triturated with $5 \mathrm{~mL}$ diethyl ether to form a yellow precipitate. DCFC afforded $163 \mathrm{mg}(23 \%)$ of yellow crystals, mp 264-266 ${ }^{\circ} \mathrm{C} \mathrm{dec} ;{ }^{1} \mathrm{H}$ NMR $\delta 1.04\left(\mathrm{~s}, 36 \mathrm{H}, \mathrm{CH}_{3}(t-\mathrm{Bu})\right)$, 1.10-1.15 (36H, $\left.\mathrm{CH}_{3}(t-\mathrm{Bu})\right), 2.11-2.15\left(\mathrm{~m}, 8 \mathrm{H}, \mathrm{CH}_{2}\right)$, 3.96-4.06 (m, 12H, CH$-\mathrm{O}), 4.43-4.48\left(\mathrm{~m}, 4 \mathrm{H}, \mathrm{CH}_{2} \mathrm{O}\right), 6.90$ (m, 2H, arom. H6), $7.02(\mathrm{~m}, 2 \mathrm{H}$, arom. H5), 7.34 (m, 2H, arom. $\mathrm{H} 3$ ); ${ }^{13} \mathrm{C}$ NMR $\delta 24.6\left(\mathrm{CH}_{3}\right), 28.0$ (two signals, $\left.\mathrm{CH}_{2}\right), 28.6$ $\left(\mathrm{CH}_{3}\right), 37.3(\mathrm{C}(t-\mathrm{Bu})), 39.5(\mathrm{C}(t-\mathrm{Bu})), 61.0$ and 61.3 (two signals, $\mathrm{CH}_{2} \mathrm{O}$ ), 64.9 (two signals, $\mathrm{CH}_{2} \mathrm{O}$ ), $66.3\left(\mathrm{CH}_{2} \mathrm{O}\right), 98.1$ (bisdioxine $\mathrm{C} 1 / \mathrm{C} 5$ ), 102.3 (two signals, bisdioxine $\mathrm{C} 4 / \mathrm{C} 8$ ), 110.4 (arom. C3), 116.0 (arom. C6), 121.3 (arom. C5), 139.5 (arom. C2), 146.6 (arom. C1/C3), 152.1 (arom. C4/C6), 163.1 (three signals, bisdioxine C3/C7), 169.4 (three signals, CO); NMR spectra were assigned on the basis of previously reported data for related bisdioxine derivatives [3-7]; IR (KBr): 3000-2800, 1720, 1619, $1535 \mathrm{~cm}^{-1}$; LC-MS m/z: $1347.8[\mathrm{M}+$ $\mathrm{H}]^{+}$; Anal. calcd for $\mathrm{C}_{72} \mathrm{H}_{102} \mathrm{~N}_{2} \mathrm{O}_{22}: \mathrm{C}, 64.16 ; \mathrm{H}, 7.63 ; \mathrm{N}, 2.08$; found: $\mathrm{C}, 63.77 ; \mathrm{H}, 7.68 ; \mathrm{N}, 1.95$.

Bis(2-amino-1,4-phenylene)macrocycle 9: A mixture of $100 \mathrm{mg}(0.07 \mathrm{mmol})$ of 8 and $40 \mathrm{mg}(2.4 \mathrm{mmol})$ of tin granules in $10 \mathrm{~mL}$ of THF was heated to reflux. Subsequently, $300 \mu \mathrm{L}$ of conc. $\mathrm{HCl}$ was added dropwise, which resulted in strong gas evolution. The reaction was followed by TLC $\left(\mathrm{CH}_{2} \mathrm{Cl}_{2} / \mathrm{MeOH}\right.$ 100:1), which indicated completion after $1 \mathrm{~h}$. The reaction mixture was cooled, neutralized with $2 \mathrm{M} \mathrm{NaOH}$, and filtered. The resulting solution was extracted with $\mathrm{CH}_{2} \mathrm{Cl}_{2}$ and concentrated, and the residue was triturated with diethyl ether, which caused the formation of a white precipitate. The product was purified by DCFC, eluting with hexane/diethyl ether/MeOH 100:30:2 to yield $10 \mathrm{mg}(10 \%)$ of a slightly yellow solid. ${ }^{1} \mathrm{H}$ NMR $\delta 1.04$ $\left(\mathrm{s}, 36 \mathrm{H}, \mathrm{CH}_{3}(t-\mathrm{Bu})\right), 1.14\left(\mathrm{~s}, 36 \mathrm{H}, \mathrm{CH}_{3}(t-\mathrm{Bu})\right), 2.06-2.08(\mathrm{~m}$, $\left.8 \mathrm{H}, \mathrm{CH}_{2}\right), 3.84-4.01\left(\mathrm{~m}, 12 \mathrm{H}, \mathrm{CH}_{2} \mathrm{O}\right), 4.45-4.48(\mathrm{~m}, 4 \mathrm{H}$, $\left.\mathrm{CH}_{2} \mathrm{O}\right), 6.10(\mathrm{~m}, 2 \mathrm{H}$, arom. H3), $6.26(\mathrm{~m}, 2 \mathrm{H}$, arom. H5), 6.52 (m, $2 \mathrm{H}$, arom. H6); ${ }^{13} \mathrm{C} \mathrm{NMR} \delta 24.6\left(\mathrm{CH}_{3}(t-\mathrm{Bu})\right), 28.2\left(\mathrm{CH}_{2}\right)$,
$28.7\left(\mathrm{CH}_{3}(t-\mathrm{Bu})\right), 37.3(\mathrm{C}(t-\mathrm{Bu})), 39.5(\mathrm{C}(t-\mathrm{Bu})), 61.6\left(\mathrm{CH}_{2} \mathrm{O}\right)$, $64.5\left(\mathrm{CH}_{2} \mathrm{O}\right), 68.2\left(\mathrm{CH}_{2} \mathrm{O}\right), 98.1$ (bisdioxine $\left.\mathrm{C} 1 / \mathrm{C} 5\right), 102.3$ (bisdioxine C4/C8), 112.2 (arom.), 114.3 (arom.), 126.6 (arom.), 128.8 (arom.), 130.9 (arom.), 153.6 (arom. C4), 163.0 (bisdioxine C3/C7), $169.6(\mathrm{CO})$; LC-MS $m / z: 1287.8[\mathrm{M}+\mathrm{H}]^{+}$; Anal. calcd for $\mathrm{C}_{72} \mathrm{H}_{106} \mathrm{~N}_{2} \mathrm{O}_{18}: \mathrm{C}, 67.15 ; \mathrm{H}, 8.30 ; \mathrm{N}, 2.18$; found: C, 67.42; H, 8.34; N, 2.16 .

4,4'-(2-Nitro-1,3-phenylene) bis(4-oxabutanol) (10): A mixture of 2-nitroresorcinol (2.5 g, $16.1 \mathrm{mmol}), 4.75 \mathrm{~g}$ (34.2 mmol) of 3-bromopropanol and $8 \mathrm{~g}(57.9 \mathrm{mmol}) \mathrm{K}_{2} \mathrm{CO}_{3}$ in $25 \mathrm{~mL}$ acetone was heated under reflux for $12 \mathrm{~h}$ under $\mathrm{N}_{2}$ with the exclusion of moisture. After cooling to rt, $100 \mathrm{~mL}$ of water was added, and the mixture was extracted with $\mathrm{CH}_{2} \mathrm{Cl}_{2}$. The organic phase was dried over $\mathrm{Na}_{2} \mathrm{SO}_{4}$ and concentrated in vacuo, and the resulting oily product was purified by DCFC, eluting with $\mathrm{CH}_{2} \mathrm{Cl}_{2} / \mathrm{MeOH} 20: 1$ to afford $1.18 \mathrm{~g}$ (27\%) of light-yellow crystals, mp $72-73{ }^{\circ} \mathrm{C} ;{ }^{1} \mathrm{H}$ NMR $\delta 1.99-2.05\left(\mathrm{~m}, 4 \mathrm{H}, \mathrm{CH}_{2}\right)$, 2.18 (s, br, 2H, OH), 3.80-3.83 (m, 4H, CH$-\mathrm{OH}), 4.20-4.23$ (m, 4H, O-CH $\mathrm{CH}_{2}$, 6.64-6.66 (m, 2H, arom. H4/H6), 7.29-7.35 $\left(\mathrm{m}, 1 \mathrm{H}\right.$, arom. H5); ${ }^{13} \mathrm{C} \mathrm{NMR} \delta 31.5\left(\mathrm{CH}_{2}\right), 59.4\left(\mathrm{CH}_{2} \mathrm{OH}\right)$, $66.6\left(\mathrm{O}-\mathrm{CH}_{2}\right), 105.5$ (arom. C4/C6), 131.3 (arom. C2), 132.3 (arom. C5), 151.3 (arom. C1/C3); LC-MS $\left(\mathrm{CH}_{2} \mathrm{Cl}_{2}\right) \mathrm{m} / \mathrm{z}$ : 271; Anal. calcd for $\mathrm{C}_{12} \mathrm{H}_{17} \mathrm{NO}_{6}$ : C, 53.13; $\mathrm{H}, 6.32 ; \mathrm{N}, 5.16$; found: C, 53.37; H, 6.42; N, 5.04.

Bis(2-nitro-1,3-phenylene)macrocycle 11: This compound was prepared from the diacid dichloride $\mathbf{3}$ and the diol $\mathbf{1 0}$ using the method described for $\mathbf{8}$. Yield $176 \mathrm{mg}$ (25\%), white crystals, mp 300-302 ${ }^{\circ} \mathrm{C} \mathrm{dec} ;{ }^{1} \mathrm{H}$ NMR $\delta 1.03$ (s, 36H, $\left.\mathrm{CH}_{3}(t-\mathrm{Bu})\right), 1.09$ (s, 36H, $\left.\mathrm{CH}_{3}(t-\mathrm{Bu})\right), 2.11-2.13\left(\mathrm{~m}, 8 \mathrm{H}, \mathrm{CH}_{2}\right), 4.00-4.06(\mathrm{~m}$, $\left.12 \mathrm{H}, \mathrm{CH}_{2} \mathrm{O}\right), 4.37-4.40\left(\mathrm{~m}, 4 \mathrm{H}, \mathrm{CH}_{2} \mathrm{O}\right), 6.44(\mathrm{~m}, 4 \mathrm{H}$, arom. $\mathrm{H} 4), 7.24\left(\mathrm{~m}, 2 \mathrm{H}\right.$, arom. H5); ${ }^{13} \mathrm{C} \mathrm{NMR} \delta 24.5\left(\mathrm{CH}_{3}-(t-\mathrm{Bu})\right)$, $27.9\left(\mathrm{CH}_{2}\right), 28.4\left(\mathrm{CH}_{3}(t-\mathrm{Bu})\right), 37.2(\mathrm{C}(t-\mathrm{Bu})), 39.4(\mathrm{C}(t-\mathrm{Bu}))$, $60.6\left(\mathrm{CH}_{2} \mathrm{O}\right), 65.4$ and 65.4 (two signals, $\left.\mathrm{CH}_{2} \mathrm{O}\right), 97.95$ and 97.98 (two signals, bisdioxine C1/C5), 102.12, 102.14 (two signals, bisdioxine C4/C8), 105.1 (arom. C4), 131.1 (arom. C2), 132.2 (arom. C5), 150.8 (arom. C1), 162.8 (two signals, bisdioxine $\mathrm{C} 3 / \mathrm{C} 7$ ), 169.2 (two signals, CO); IR (KBr) 2800-3000, 1721, 1615, $1541 \mathrm{~cm}^{-1}$; LC-MS m/z: $1347.5[\mathrm{M}+$ $\mathrm{H}]^{+}$; Anal. calcd for $\mathrm{C}_{72} \mathrm{H}_{102} \mathrm{~N}_{2} \mathrm{O}_{22}: \mathrm{C}, 64.16 ; \mathrm{H}, 7.63 ; \mathrm{N}, 2.08$; found: C, 64.32; H, 7.82; N, 2.07.

Bis(2-amino-1,3-phenylene)macrocycle 13: The dinitro compound 11 (44 mg; $0.03 \mathrm{mmol}$ ) was reduced with $20 \mathrm{mg}$ (1.69 mmol) of tin granules in $5 \mathrm{~mL}$ of THF and $150 \mu \mathrm{L}$ of conc. $\mathrm{HCl}$, as described for the reduction of $\mathbf{8}$ above. It took $3 \mathrm{~h}$ for the starting material to be fully consumed, yielding $10 \mathrm{mg}$ of the diamine as a white precipitate. ${ }^{1} \mathrm{H}$ NMR $\delta 1.04-1.16(\mathrm{~m}$, $72 \mathrm{H}, t-\mathrm{Bu}), 2.18\left(\mathrm{~m}, 8 \mathrm{H}, \mathrm{CH}_{2}\right), 3.99-4.01\left(\mathrm{~m}, 12 \mathrm{H}, \mathrm{CH}_{2} \mathrm{O}\right)$, $4.38-4.58\left(\mathrm{~m}, 4 \mathrm{H}, \mathrm{CH}_{2} \mathrm{O}\right), 6.25-6.50(\mathrm{~m}, 6 \mathrm{H}$, arom. H4, H5, 
H6); ${ }^{13} \mathrm{C}$ NMR $\delta 24.6\left(\mathrm{CH}_{3}(t-\mathrm{Bu})\right), 28.5\left(\mathrm{CH}_{3}(t-\mathrm{Bu})\right), 29.7$ $\left(\mathrm{CH}_{2}\right), 37.4(\mathrm{C}(t-\mathrm{Bu})), 39.5(\mathrm{C}(t-\mathrm{Bu})), 61.4\left(\mathrm{CH}_{2} \mathrm{O}\right), 64.5$ $\left(\mathrm{CH}_{2} \mathrm{O}\right), 98.1$ (bisdioxine $\mathrm{C} 1 / \mathrm{C} 5$ ), 102.3 (bisdioxine $\mathrm{C} 4 / \mathrm{C} 8$ ), 104.9 (arom. C4/C6), 117.0 (arom. C5), 146.4 (arom. C1/C3), 163.0 (bisdioxine $\mathrm{C} 3 / \mathrm{C} 7), 169.5$ (CO); the aromatic $\mathrm{C} 2$ signal was not observed because of broadening owing to the nitrogen quadrupole moment; LC-MS $m / z: 1287.5[\mathrm{M}+\mathrm{H}]^{+}$. The LC-MS indicated the presence of the mono-amine $\mathbf{1 2}$ as an impurity, $m / z: 1317.5[\mathrm{M}+\mathrm{H}]^{+}$.

Tetraoxaadamantane 14: To a solution of $50 \mathrm{mg}$ of dinitro compound 8 in $1 \mathrm{~mL}$ of $\mathrm{CH}_{2} \mathrm{Cl}_{2}$ and $1 \mathrm{~mL}$ of glacial acetic acid was added $55 \mu \mathrm{L}$ of conc. $\mathrm{HCl}$, and the resulting mixture was stirred in a closed flask at $\mathrm{rt}$ for $48 \mathrm{~h}$. The $\mathrm{CH}_{2} \mathrm{Cl}_{2}$ was evaporated, and the formed precipitate was purified by DCFC, eluting with $\mathrm{CH}_{2} \mathrm{Cl}_{2} / \mathrm{MeOH} 100: 1$ to yield $10 \mathrm{mg}(20 \%)$ of yellow crystals. ${ }^{1} \mathrm{H}$ NMR $\delta 0.68-1.26\left(\mathrm{~m}, 72 \mathrm{H}, \mathrm{CH}_{3}(t-\mathrm{Bu})\right), 2.18(\mathrm{br}$, $8 \mathrm{H}, \mathrm{CH}_{2}$ ), 2.77-2.82 (two signals, $2 \mathrm{H}$, tetraoxaadamantane $\mathrm{CH}), 4.07-4.45\left(\mathrm{~m}, 16 \mathrm{H}, \mathrm{CH}_{2} \mathrm{O}\right), 7.02(2 \mathrm{H}$, arom. H6), $7.05(\mathrm{~m}$, $2 \mathrm{H}$, arom. H5), 7.40 (m, 2H, arom. H3); HMBC-2D $\delta 7.02,7.05$ and 7.40 (arom. H6, H5 and H3), 99.9 (bisdioxine C1/C5), 99.4 (tetraoxaadamantane $\mathrm{C} 1 / \mathrm{C} 3$ ), 100.8 (tetraoxaadamantane $\mathrm{C} 5 /$ C7), 109.7 (arom. C3), 115.5 (arom. C6), 121.8 (arom. C5), 138.8 (arom. C2), 146.6 (arom. C1), 152.0 (arom. C4), 162.5, 162.7 (bisdioxine C3/C7), 167.8 (CO), 168.1 (CO), 174.8 (CO); HMQC-2D $\delta 24.7,24.9\left(\mathrm{CH}_{3}(t-\mathrm{Bu})\right), 27.5\left(\mathrm{CH}_{2}\right), 43.5$ (tetraoxaadamantane $\mathrm{CH}), 60.0\left(\mathrm{CH}_{2} \mathrm{O}\right), 64.0\left(\mathrm{CH}_{2} \mathrm{O}\right), 65.3\left(\mathrm{CH}_{2} \mathrm{O}\right)$, 109.8 (arom. C3), 115.0 (arom. C6), 121.6 (arom. C5); LC-MS $m / z: 1382.8\left[\mathrm{M}+\mathrm{H}_{2} \mathrm{O}\right]^{+}$; Anal. calcd for $\mathrm{C}_{72} \mathrm{H}_{104} \mathrm{~N}_{2} \mathrm{O}_{23}: \mathrm{C}$, 63.31; H, 7.68; N, 2.05; found: C, 63.65; H, 8.55; N, 1.97 .

\section{Supporting Information}

\section{Supporting Information File 1}

Drawings of the $R$ and $S$ enantiomers of $\mathbf{3}$ and the $R, S$ (meso), $R, R$, and $S, S$ diastereoisomers of the bisdioxine macrocyles.

[http://www.beilstein-journals.org/bjoc/content/ supplementary/1860-5397-8-83-S1.pdf]

\section{Supporting Information File 2}

Assignment of ${ }^{1} \mathrm{H}$ NMR spectra and copies of ${ }^{13} \mathrm{C}$ NMR spectra of $8, \mathbf{1 1}$, and $\mathbf{1 3}$.

[http://www.beilstein-journals.org/bjoc/content/ supplementary/1860-5397-8-83-S2.pdf]
(UQ) and Prof. Klaus Zangger (Graz) for the recording of NMR spectra. SL gratefully acknowledges the award of a Visiting Scholar stipend at UQ.

\section{References}

1. Kremsner, J.; Wallfisch, B. C.; Belaj, F.; Uray, G.; Kappe, C. O.; Wentrup, C.; Kollenz, G. Eur. J. Org. Chem. 2008, 3382-3388. doi:10.1002/ejoc.200800109

2. Kappe, C. O.; Faerber, G.; Wentrup, C.; Kollenz, G. J. Org. Chem. 1992, 57, 7078-7083. doi:10.1021/j000052a018

3. Kappe, C. O.; Kollenz, G.; Fabian, W. M. F.; Wentrup, C.; Faerber, G. J. Org. Chem. 1993, 58, 3361-3367. doi:10.1021/jo00064a024

4. Wallfisch, B. C.; Egger, T.; Heilmayer, W.; Kappe, C. O.; Wentrup, C.; Gloe, K.; Belaj, F.; Klintschar, G.; Kollenz, G. Supramol. Chem. 2002, 14, 383-396. doi:10.1080/1061027021000003430

5. Chebanov, V. A.; Reidlinger, C.; Kanaani, H.; Wentrup, C.; Kappe, C. O.; Kollenz, G. Supramol. Chem. 2004, 16, 121-127. doi:10.1080/10610270310001614197

6. Haberz, P.; Belaj, F.; Gloe, K.; Wentrup, C.; Kollenz, G. Supramol. Chem. 2012, 24, in press. doi:10.1080/10610278.2012.658393

7. Heilmayer, W.; Wallfisch, B. C.; Kappe, C. O.; Wentrup, C.; Gloe, K.; Kollenz, G. Supramol. Chem. 2003, 15, 375-383. doi:10.1080/1061027031000108848

8. Okazaki, R.; Goto, K. Heteroat. Chem. 2002, 13, 414-418. doi:10.1002/hc.10068

9. Watanabe, S.; Goto, K.; Kawashima, T.; Okazaki, R. J. Am. Chem. Soc. 1997, 119, 3195-3196. doi:10.1021/ja963093m

10. Shimada, K.; Goto, K.; Kawashima, T.; Takagi, N.; Choe, Y.-K.; Nagase, S. J. Am. Chem. Soc. 2004, 126, 13238-13239. doi:10.1021/ja0457009

11. Goto, K.; Sonoda, D.; Shimada, K.; Sase, S.; Kawashima, T. Angew. Chem., Int. Ed. 2010, 49, 545-547. doi:10.1002/anie.200905796 Angew. Chem. 2010, 122, 555-557. doi:10.1002/ange.200905796 12. Goto, K.; Shimo, I.; Kawashima, T. Bull. Chem. Soc. Jpn. 2003, 76, 2389-2394. doi:10.1246/bcsj.76.2389

13. Panek, J. S.; Xu, F.; Rondón, A. C. J. Am. Chem. Soc. 1998, 120, 4113-4122. doi:10.1021/ja974318b

14. Stiasni, N.; Kappe, C. O. ARKIVOC 2002, (viii), 71-79.

15. Heilmayer, W.; Smounig, R.; Gruber, K.; Fabian, W. M. F.; Reidlinger, C.; Kappe, C. O.; Wentrup, C.; Kollenz, G. Tetrahedron 2004, 60, 2857-2867. doi:10.1016/j.tet.2004.01.058

16. SYBYL 6.9 Molecular Modeling Software; Tripos Inc.: St. Louis, MO, USA.

17. Harwood, L. M. Aldrichimica Acta 1985, 18, 25.

18. Dolson, M. G.; Swenton, J. S. J. Am. Chem. Soc. 1981, 103, 2361-2371. doi:10.1021/ja00399a037

\section{Acknowledgements}

This work was supported by the Karl Franzens Universität Graz, The University of Queensland, and the Australian Research Council. We are indebted to Ms Lynette Lambert 


\section{License and Terms}

This is an Open Access article under the terms of the Creative Commons Attribution License

(http://creativecommons.org/licenses/by/2.0), which permits unrestricted use, distribution, and reproduction in any medium, provided the original work is properly cited.

The license is subject to the Beilstein Journal of Organic Chemistry terms and conditions:

(http://www.beilstein-journals.org/bjoc)

The definitive version of this article is the electronic one which can be found at:

doi:10.3762/bjoc. 8.83 